\title{
Analysis of the Effect of Leadership, Job Motivation, and Organizational Culture Towards the Employee Performance of STT PLN
}

\author{
Susanto*, Lannodaya Tommy Syahputra \\ STIE Bisnis Indonesia \\ Jakarta, Indonesia \\ *susanto@stiebi.ac.id
}

\begin{abstract}
The purpose of this study was to determine the effect of leadership, job motivation, and organizational culture on employee performance. The sampling technique used purposive sampling and a sample of 100 employees of the PLN Technical College. The analysis technique uses multiple regression analysis. The results showed that partially or simultaneously the variables of leadership, job motivation, and organizational culture significantly influence employee performance.
\end{abstract}

Keywords-leadership, job motivation, organizational culture, and employee performance

\section{INTRODUCTION}

PT PLN (Persero) as a educational institution established by the State Electric Company Foundation, established on April 1, 1998 and received permission from the Minister of Education through a registered permit under D/0/1/1998 dated 31 March 1998 operates by organizing education for the first time by acquiring 303 students and currently after more than 19 years of operation the number of students reaches 3,500 students. As one of the technical tertiary institutions, the PLN Technical College (STT-PLN) prioritizes the quality of its education, including by completing supporting facilities; the construction of very complete laboratories, a very adequate library, a highly reliable technology-based university management information system, and the provision of qualified academic and non-academic personnel makes STT-PLN get very significant students from year to year.

STT-PLN was established in addition to aiming to educate the life of the nation as well as aiming at becoming an Excellent University and if it was achieved then it could be said to be successful. To achieve this success, we need a strong foundation in the form of the formation of an individual and group expertise as well as a good and conducive work climate. Besides that, it is also necessary to give awards in the form of incentives and increase work motivation that can increase employee job satisfaction. Human resources at PT PLN (Persero) 's Foundation for Education and Welfare Engineering is a very important and very valuable asset. The achievement of maximum work results will be greatly supported by the increasing role of leaders from the Chair level to the Section involved in managing human resources. At present the aspect of developing human resources has received special attention from the management of STT-PLN.

\section{LITERATURE REVIEW}

Leadership is any action carried out by individuals or groups to coordinate and give direction to individuals or groups who are incorporated in a particular container to achieve the goals that have been set [1]. Meanwhile, it is the ability to convince and move others to want to work together under his leadership as a team to achieve a certain goal $[2,3]$.

Motivation is the process of influencing or encouraging from outside towards a person or working group so that they want to carry out something that has been determined [2]. Meanwhile, the importance of motivation because motivation is the thing that causes, channeling [4]. Motivation is a series of attitudes and values that influence individuals to achieve specific things [5]. Motivation is an urge or will that cause someone to do something [6]. Furthermore, Motivation is a driving force for someone to carry out an activity to achieve goals [7].

Organizational culture is a pattern of values, norms, beliefs, attitudes and assumptions that cannot be articulated, but rather shape and determine how people behave and get things done [8]. Organizational culture is a belief, values and general perception that is widely held in shaping and giving meaning to employee behavior so that it becomes a habit that is relatively difficult to change.

Work performance is a result achieved by a person according to the applicable standards $[9,10]$. Meanwhile, Performance is the result obtained by an organization both the organization is profit oriented and nonprofit oriented which is produced during a period of time [11].

This research is a survey research. Sample used an official employee and were recorded as active working at the Jakarta Technical College Jakarta. Purposive sampling is a sampling technique with certain considerations. With this technique, researchers make a judgment by assuming that the selected 
employees are considered to know more than others [12]. The type of purposive sampling chosen was judgment sampling because the selection of 100 sampling members was adjusted to several criteria to be determined by the researcher subjectively to obtain sample members who could provide the data and information needed in conducting the analysis in this study. Multiple linear regression analysis was used to analyze.

\section{RESULTS AND DISCUSSION}

\section{A. Results}

Validity and reliability tests are declared valid and reliable so that the test is forwarded to the classical assumption test. In the normality test, it is stated that the normal data is by analyzing the P-plot graph. Data does not occur heteroscedasticity as seen from scatterplot graph analysis results where the points do not form certain patterns. The results of multicollinearity test show there is no multicollinearity with a VIF value <10. After the classic assumption test, the hypothesis test continues as shown in the table below:

TABLE I. PARTIAL TEST Results

\begin{tabular}{|l|c|c|c|}
\hline \multicolumn{1}{|c|}{ Variable } & B & t & Sig. \\
\hline Leadership & 0.231 & 3.377 & 0.002 \\
\hline Job Motivation & 0.417 & 4.956 & 0.000 \\
\hline Organizational Culture & 0.306 & 4.133 & 0.000 \\
\hline
\end{tabular}

\section{B. Discussion}

Table 1 showed the leadership, job motivation, and organizational culture has a positive impact on employee performance. All the significance values is less than error term or $5 \%$, this means that the assumptions in hypotheses 1, 2 and 3 are accepted.

TABLE II. Simultaneous Test Results

\begin{tabular}{|l|l|l|l|l|l|}
\hline \multicolumn{1}{|c|}{ Model } & \multicolumn{1}{|c|}{$\begin{array}{c}\text { Sum of } \\
\text { Squares }\end{array}$} & df & $\begin{array}{c}\text { Mean } \\
\text { Square }\end{array}$ & F & Sig. \\
\hline Regression & 27.306 & 3 & 9.102 & 19.497 & 0.000 \\
\hline Residual & 92.004 & 96 & 0.958 & & \\
\hline Total & 119.310 & 99 & & & \\
\hline
\end{tabular}

Simultaneous test results are shown in table 2 above, the assumption in hypotheses 4 is accepted with the significance value of $0.000<0.05$ which means leadership, job motivation, and organizational culture together influence employee performance.

The coefficient of determination the adjusted $\mathrm{R}$ square value of 0.682 , which means leadership, job motivation, and organizational culture to employee performance by $68.2 \%$ and the rest is influenced by other factors not examined.

\section{CONCLUSION}

Based on the results of research and analysis that has been done, the following general conclusions are obtained, employee performance is positively and significantly influenced by leadership, job motivation, and organizational culture. The main finding of this research is that employee performance is most strongly influenced by organizational culture variables.

\section{REFERENCES}

[1] D. Sudarwan, "Motivasi, Kepemimpinan dan Efektivitas Kelompok, cet,” Ke-1, Jakarta PT. Rineka Cipta, 2004.

[2] S. Samsudin, "Manajemen Sumber Daya Manusia, Cet," Ketiga, Bandung: Pustaka Setia, 2010.

[3] S. P. Robbins and M. Coulter, Manajemen, Edisi Kese. Jakarta: Erlangga, 2010.

[4] M. S. P. Hasibuan, "Manajemen sumber daya manusia, Cetakan ketujuh,” Jakarta PT. Bumi Aksara, 2009.

[5] V. R. Zainal, “dkk.(2014), Manajemen Sumber Daya Manusia untuk Perusahaan dari Teori ke Praktik,” Ed. ketiga. Jakarta PT RajaGrafindo Persada Rajawali Pers.

[6] H. Nawawi, Kepemimpinan Mengefektifkan Organisasi. Yogyakarta: UGM Gajah Mada University, 2006.

[7] T. Miftah, "Perilaku Organisasi Konsep Dasar dan Aplikasinya, PT," Raja Graf. Persada, Jakarta, 2012.

[8] N. Chatab, Profil Budaya Organisasi. Bandung: Penerbit Alfabeta, 2007.

[9] H. Suwatno and D. J. Priansa, "Manajemen SDM dalam organisasi Publik dan Bisnis,” Bandung Alf., 2011.

[10] Wirawan, Evaluasi Kinerja Sumber Daya Manusia. Jakarta: Salemba Empat, 2009.

[11] I. Fahmi, Manajemen Teori, Kasus, dan Solusi. Bandung: ALFABETA, 2011.

[12] A. Suharsimi, "Prosedur penelitian: suatu pendekatan praktik (edisi revisi)," Jakarta: Rineka Cipta, vol. 1, 2010. 